\title{
Hubungan Kehamilan terhadap Fungsi Seksual Wanita Usia 20-35 Tahun di Kecamatan Singaran Pati Kota Bengkulu
}

\author{
Madonna Fitri Pasaribu ${ }^{1}$, Taufiq Ramadhan ${ }^{2}$, Enny Nugraheni ${ }^{1}$ \\ ${ }^{1}$ Fakultas Kedokteran dan Ilmu Kesehatan Universitas Bengkulu \\ ${ }^{2}$ Departemen Obstetri dan Ginekologi RSUD dr. M. Yunus Bengkulu
}

\begin{abstract}
ABSTRAK
Latar Belakang: Perubahan seksual selama kehamilan terkadang dianggap sesuatu yang tidak penting atau tabu untuk dibicarakan. Apabila kebutuhan seksual yang bersifat fisiologis dan dasar tersebut tidak terpenuhi maka akan menimbulakan masalah psikis bagi ibu hamil maupun pasangannya bahkan dapat memicu keretakkan rumah tangga hingga terjadi perceraian.

Metode:Penelitian ini merupakan penelitian analitik observasional dengan desain potong lintang. 108 orang wanita hamil usia 20-35 tahun sampel diambil dengan metode consecutive samplingdi Kecamatan Singaran Pati Kota Bengkulu. Fungsi seksual dinilai menggunakan kuesioner Female Sexual Function Index (FSFI). Sebaran data diuji dengan uji Kolmogorov-Smirnov. Analisis hubungan antara dua variabel kategorik dengan uji Chi-square.

Hasil Penelitian:Berdasarkan penelitian didapatkan sampel dengan rentang usia 20-35 tahun dengan frekuensi terbanyak pada usia 29 dan 30 tahun, dimana sebagian besar memiliki riwayat melahirkan satu kali (primipara) dan berprofesi sebagai ibu rumah tangga dengan pendidikan terakhir adalah SMA/sederajat.Nilai total fungsi seksual ibu hamil di Kecamatan Singaran Pati adalah normal sebanyak 87 orang $(80,6 \%)$ dengan kepuasan seksual $98,15 \%$.Seiring bertambahnya usia kehamilan akan menyebabkan peningkatan kecendrungan terjadinya ganggguan fungsi seksual. Pada trimester 1 terdapat 2 orang sampel mengalami gangguan fungsi seksual dan adanya peningkatan pada trimester II 6 orang dan trimester III 13 orang. Terdapat hubungan yang signifikan antara kehamilan terhadap domain kemauan $(p=0,000)$ dan pada domain gairah $(p=0,000)$.

Kesimpulan:Adanya hubungan yang signifikan antara kehamilan terhadap fungsi seksual ibu hamil $(p<0,05)$.
\end{abstract}

Kata kunci: kehamilan, fungsi seksual wanita, kuesioner FSFI

\section{Association of Pregnancy to 20-35 Female Sexual Functions in Singaran Pati District, Bengkulu}

\begin{abstract}
Background: Sexual changes during pregnancy is sometimes being taboo to talk. If the physiologic sexual are not fulfilled so it will effect psychological problems for mothers and their partner that will be able to trigger divorce.

Method:This research was an analytical observational by cross sectional design. Samples were collected from 108 pregnant mothers who are 20-35 years old by using consecutive sampling. Sexual function were measured by Female Sexual Function Index (FSFI) questionnaire. Data distribution were analyzed by Kolmogorov-Smirnov tests. Association of two variables were analyzed by Chisquare test.

Result:Samples are in 20-35 years old, primipara, worked as housewife, and educated as senior high school. Total sexual fuction are in normal $(80,6 \%)$, by sexual satisfaction are $98,15 \%$. By enhancement of age may improve possibility of sexual disfunction. Samples with sexual disfunction consists of 2 samples In the first semester, 6 samples in second trimester, and 13 samples third trimester. There are significant association between pregnancy and desire domain $(p=0,000)$ and arousal domain $(\mathrm{p}=0,000)$.

Conclusion: There are significant between pregnancy and sexual disfunction $(p<0,05)$.
\end{abstract}

Keywords: Pregnancy, Female sexual function, FSFI questionnaire 


\section{PENDAHULUAN}

Seksualitas merupakan kebutuhan dasar manusia yang terdiri atas motivasi, perasaan, pikiran, perilaku ditentukan oleh kebutuhan biologis (nafsu dan reproduksi), kebutuhan psikologis seperti cinta, kasih sayang, dan hubungan yang intim terhadap pasangan. ${ }^{1}$ Fungsi seksual dipengaruhi oleh usia, pengetahuan, penyakit kronik, hormon seksual, kehamilan dan persalinan. Gangguan fungsi seksual dapat mempengaruhi kualitas hidup wanita dan memiliki efek negatif pada rasa percaya diri. $^{2}$ Dalam sebuah populasi umum wanita dapat mengalami gangguan fungsi seksual sebesar $40-50 \%$ selama hidupnya. ${ }^{3}$

Kehamilan merupakan suatu peristiwa yang penting dalam kehidupan wanita. Suatu peristiwa yang dimulai sejak terjadinya konsepsi sampai keluarnya hasil konsepsi dari rahim. Kehamilan memiliki peran penting dalam fungsi seksual dan perilaku wanita. Berdasarkan penelitian pada 298 orang wanita hamil di Cina, $80 \%$ wanita hamil dan pasangannya khawatir apabila melakukan hubungan seksual selama kehamilan akan memberi efek terhadap janinnya sehingga mereka enggan untuk melakukan aktivitas seksual selama kehamilan. ${ }^{4}$ Perubahan seksual selama kehamilan ini terkadang dianggap sesuatu yang tidak penting atau tabu untuk dibicarakan. Padahal perubahan selama kehamilan memerlukan penyusaian diri antara suami istri dan bahkan memerlukan bantuan tenaga profesional. Namun perlu diperhatikan bagaimana cara pemenuhan akan seksual tersebut. Apabila kebutuhan seksual yang bersifat fisiologis dan dasar tersebut tidak terpenuhi maka akan menimbulkan masalah psikis bagi ibu hamil maupun pasangannya bahkan dapat memicu keretakan dalam rumah tangga hingga terjadinya perceraian. ${ }^{5}$

Berdasarkan uraian diatas dan penelusuran pustaka yang ada, peneliti tertarik untuk melaksanakan penelitian tentang hubungan kehamilan terhadap fungsi seksual pada wanita usia $20-35$ tahun yang belum pernah dilakukan khususnya di Kecamatan Singaran Pati.

\section{METODE}

Penelitian ini menggunakan rancangan penelitian analitik observasional dengan studi kros-seksional. Subjek pada penelitian ini adalah ibu hamil yang berada wilayah kerja Kecamatan Singaran Pati khususnya pada Puskesmas Lingkar Timur dan Puskesmas Jembatan Kecil pada periode penelitian yang memenuhi kriteria inklusi.. Penelitian ini dilaksanakan pada bulan Mei 2016. Sebanyak 
108 orang sampel penelitian diambil dengan menggunakan teknik consecutive sampling.

Kehamilan dinilai dengan wawancara dan observasi buku KIA, sedangkan fungsi seksual diukur dengan menggunakan alat kuesioner FSFI. Uji analisis pada penelitian ini menggunakan program SPSS 21 dengan taraf signifikansi atau batas kepercayaan adalah 0,05 . Analisis sebaran data diuji dengan uji Kolmogorov-smirnov. Analisis bivariat dianalisis dengan uji chi-square $\left(\mathrm{x}^{2}\right)$.

\section{HASIL}

\section{Karakteristik Subjek Penelitian}

Didapatkan hasil persentase usia subjek penelitian paling banyak terdapat pada usia 29 dan 30 tahun sebanyak 13 orang $(12,0 \%)$, paling sedikit usia subjek penelitian pada usia 20 tahun. Jumlah ibu hamil berdasarkan usia kehamilan sama banyak yaitu 36 orang tiap trimesternya. Subjek penelitian paling banyak memiliki jumlah paritas primipara $(43,5 \%)$, dan jumlah ibu yang belum pernah melahirkan ( $23,1 \%)$. Subjek penelitian paling banyak berprofesi IRT (41,7\%), dan sebagian kesil PNS (2,8\%). Pendidikan terakhir subjek penelitian terbanyak lulusan SMA (58,3\%) dan pendidikan terendah yaitu SD (6,5\%).

\section{Distribusi Frekuensi Nilai Fungsi Seksual}

Subjek Penelitian

Pada Tabel 1 diperoleh sebagian besar subjek penelitian tidak memiliki gangguan fungsi seksual $(80,6 \%)$, dengan tingkat kepuasan seksual $98,15 \%$.

Tabel 1 Distribusi Frekuensi Nilai Fungsi dan Kepuasan Seksual Subjek Penelitian

\begin{tabular}{ll}
\hline \multicolumn{1}{c}{ Variabel } & Hasil Pengukuran $(\%)$ \\
\hline Fungsi Seksual & \\
- Ada gangguan & $21(19,4 \%)$ \\
- Tidak ada gangguan & $87(80,6 \%)$ \\
Kepuasan seksual & \\
- Puas & $106(98,15 \%)$ \\
- Tidak puas & $2(1,85 \%)$ \\
\hline
\end{tabular}




\section{Hubungan Usia Kehamilan terhadap Fungsi}

Seksual dan Domain Fungsi Seksual

Pengukuran dengan menggunakan

kuesioner female sexual function index didapatkan adanya hubungan yang signifikan antara kehamilan terhadap fungsi seksual ibu hamil $(p<0,05)$.Selain itu, didapatkan adanya hubungan yang signifikan antara usia kehamilan dengan domain kemauan $(p=0,000)$ dan adanya hubungan yang signifikan antara usia kehamilan dengan domain gairah $(p=0,000)$ seperti yang tampak pada tabel 2 .

Setelah dilakukan penggabungan sel dan dianalisis kembali menggunakan uji chisquare namun didapatkan hasil bahwa uji chisquare tidak memenuhi syarat oleh karena itu dilakukan uji alternatif menggunakan uji fisher didapatkan hasil bahwa tidak ada hubungan yang signifikan antara kehamilan terhadap domain lubrikasi $(p>0,05)$, tidak terdapat hubungan yang signifikan antara kehamilan terhadap domain orgasme $(p>0,05)$, tidak terdapat hubungan yang signifikan antara kehamilan terhadap domain kepuasan, dan tidak terdapat hubungan yang signifikan antara kehamilan terhadap domain nyeri $(p>0,05)$ yang dapat dilihat pada tabel 3 .

\section{PEMBAHASAN}

\section{Karakteristik subjek penelitian}

Hasil persentase usia subjek penelitian paling banyak terdapat pada usia 29 dan 30 tahun sebanyak 13 orang $(12,0 \%)$. Subjek penelitian sebagian besar memiliki jumlah paritas primipara $(43,5 \%)$, lulusan SMA (58,30\%), dan pekerjaan IRT $(41,7,0 \%)$. Frekuensi seksual meningkat pada usia yang lebih muda dan berpenghasilan tinggi. Aktifitas seksual menurun seiring dengan bertambahnya usia, tetapi meningkat pada lansia dengan pendidikan dan pendapatan yang tinggi serta masih dalam ikatan perkawinan. Tingkat pendidikan yang rendah pada wanita meningkatkan risiko terjadinya disfungsi seksual. ${ }^{6}$

\section{Distribusi Frekuensi Nilai Fungsi Seksual}

\section{Ibu Hamil}

Nilai total fungsi seksual sebagian besar subjek penelitian adalah fungsi seksual yang normal. Seksualitas merupakan suatu komponen integral dari kehidupan seorang wanita normal. Hubungan seksual yang nyaman dan memuaskan merupakan salah satu faktor yang berperan penting dalam hubungan perkawinan bagi banyak pasangan. ${ }^{8}$ 
Tabel 2. Hubungan Kehamilan terhadap Fungsi Seksual Subjek Penelitian

\begin{tabular}{cccccccc}
\hline & & \multicolumn{5}{c}{ Kehamilan } & \\
\cline { 3 - 5 } & & Trimester & Trimester & Trimester & Total & Nilai $p$ \\
\hline Fungsi & Ada gangguan & 2 & 34 & 13 & 21 & \\
seksual & Tidak ada gangguan & 34 & 30 & 23 & 87 & 0,004 \\
Domain & Ada Gangguan & 0 & 8 & 19 & 27 & 0,000 \\
kemauan & Tidak Ada Gangguan & 36 & 28 & 17 & 81 & \\
Domain & Ada Gangguan & 1 & 6 & 16 & 23 & 0,000 \\
Gairah & Tidak Ada Gangguan & 35 & 30 & 20 & 85 & \\
\hline
\end{tabular}

Nilai $p$ bermakna jika $p<0,05$.

Tabel 3. Hubungan Kehamilan terhadap Fungsi Seksual Subjek Penelitian

\begin{tabular}{ccccccc}
\hline & & \multicolumn{3}{c}{ Kehamilan } & & \\
\cline { 3 - 5 } & & Trimester I dan II & Trimester III & Total & Nilai p \\
\hline \multirow{2}{*}{ Domain Lubrikasi } & Ada Gangguan & 2 & 1 & 3 & 1,000 \\
& Tidak Ada Gangguan & 70 & 35 & 105 & \\
Domain Orgasme & Ada Gangguan & 0 & 1 & 1 & 0,333 \\
& Tidak Ada Gangguan & 72 & 35 & 107 & \\
Domain Kepuasan & Ada Gangguan & 1 & 1 & 2 & 1,000 \\
& Tidak Ada Gangguan & 71 & 35 & 106 & \\
Domain Nyeri & Ada Gangguan & 5 & 2 & 7 & 1,000 \\
& Tidak Ada Gangguan & 67 & 34 & 101 & \\
\hline
\end{tabular}

Nilai $p$ bermakna jika $p<0,05$

Fungsi seksual dalam kehamilan dipengaruhi oleh beberapa faktor, diantaranya yaitu faktor hormonal, neurogenik, fisik, maupun psikis. Hormon testosteron berperan penting dalam seksualitas pria maupun wanita, yang berpengaruh pada hasrat dan aktivitas seksual. Pada wanita hamil, terjadi penurunan kadar terstosteron dan hasrat seksual. ${ }^{9}$

$$
\text { Dopamin, merupakan suatu }
$$

neurotransmiter yang aktif pada saat tubuh dalam keadaan senang. Dorongan atau keinginan seksual diaktivasi oleh dopamin, yang menyebabkan peningkatanhasrat seksual. Meskipun faktor hormonal dan neurogenik memegang peranan dalam fungsi seksual, namun sekitar $46 \%$ disfungsi seksual dalam kehamilan lebih dipengaruhi oleh ketidaknyaman fisik, dan 25\%-50\% dipengaruhi oleh faktor psikis. ${ }^{9}$

\section{Distribusi Frekuensi kepuasan fungsi seksual ibu hamil \\ Pada penelitian di dapatkan sebagian besar ibu hamil di kecamatan Singaran Pati puas terhadap kehidupan}


seksualnya yaitu sebanyak 98,15\% (106 orang). Penelitian ini sejalan dengan penelitian Pauleta et al didapatkan hasil bahwa tidak terdapat perubahan kepuasan seksual selama kehamilan dibandingkan dengan sebelum kehamilan sebesar $48,4 \%$, terjadi peningkatan kepuasan seksual selama kehamilan sebesar $14,9 \%$, terjadi penurunan kepuasan seksual selama kehamilan sebanyak $27,7 \%$, dan $9 \%$ ibu hamil tidak menjawab kuesioner yang diberikan. Dapat kita lihat bahwa pada kondisi hamil tidak mempengaruhi kepuasan seksual ibu hamil. ${ }^{10}$ Jika ibu hamil merasakan kenyamanan, merasakan ketenangan maka dopamin akan aktif dan meningkatkan dorongan atau hasrat seksual. $^{9}$

\section{Hubungan Usia Kehamilan Terhadap Fungsi Seksual}

Berdasarkan hasil uji Chi-square analisis hubungan usia kehamilan dengan fungsi seksual didapatkan nilai $p=0,004$. Hal ini berarti bahwa terdapat hubungan yang signifikan antara usia kehamilan dengan fungsi seksual. Hasil penelitian ini sesuai dengan penelitian yang telah dilakukan kuljarusnont et al bahwa seiring bertambahnya usia kehamilan maka akan terjadi penurunan fungsi seksual. ${ }^{11}$

Pada penelitian Corbacioglu et al terdapat penurunan aktivitas seksual dan nilai
FSFI pada wanita yang menyadari kehamilannya di bandingkan mereka yang belum menyadari kehamilannya. ${ }^{12}$ Penelitian Leite AP menunjukkan dimana fungsi seksual wanita hamil pada trimester I dan II memiliki pola yang hampir mirip namun pada trimester III mempelihatkan penurunan yang signifikan. ${ }^{2}$

\section{Hubungan Kehamilan Terhadap Distribusi Gangguan Seksual Berdasarkan Domain Fungsi Seksual}

Pada hasil terdapat hubungan antara kehamilan terhadap fungsi seksual domain kemauan dan gairah. Gangguan fungsi seksual pada domain kemauan dan gairah semakin meningkat seiring bertambahnya usia kehamilan. Pada domain kemauan tidak terdapat gangguan pada trimester I namun pada trimester II terdapat 8 orang ibu hamil mengalami gangguan fungsi seksual pada domain kemauan dan 19 orang gangguan fungsi seksual pada trimester III.

$$
\text { Pada kehamilan akan terjadi }
$$
peningkatan vaskularisasi pada vagina dan visera yang akan meningkatkan sensitivitas organ genital eksterna sehingga akan meningkatkan kemauan dan gairah seksual. ${ }^{13}$ Ketika terjadi rangsangan lokal pada klitoris akan mengaktifkan saraf parasimpatis, dimana saraf ini berjalan bilateral pada kelenjar 
batholini yang akan meningkatkan produksi mukus pada epitel vagina sehingga peningkatan sekresi mukus saat berhubungan seksual akan memberikan sensasi pijatan dan mengurangi rasa nyeri. $^{14}$ Saat mencapai orgasme akan meningkatkan kontraksi otot tubuh, ekstremitas, otot uterus, otot vagina dan perineum. Pada saat ini gerakan janin berkurang dan terjadi deselerasi, hal ini tidak akan membahayakan janin. Melakukan senggama dan orgasme saja tidak dapat memicu persalinan pada wanita yang normal. $^{15}$

Pada kehamilan peran suami sangat penting. Bagaimana suami akan memberikan rasa nyaman, aman, percaya diri, merasa dihargai akan memberikan dampak positif terhadap emosional ibu hamil. Emosional yang positif akan menimbulkan dampak positif terhadap kepuasan seksual ibu hamil. ${ }^{2}$

Gangguan fungsi seksual pada domain kemauan dan gairah meningkat seiring bertambahnya usia kehamilan. Gangguan pada domain tersebut berkaitan erat dengan adanya peningkatan kadar hormon estrogen, progesteron, dan prolaktin. Peningkatan kadar hormon tersebut akan menimbulkan munculnya gejala mual, muntah, berat badan bertambah, kelelahan, nyeri payudara. ${ }^{5}$ Oleh karena itu pada trimester III gangguan pada domain kemauan dan gairah meningkat.

Penurunan aktivitas dan keinginan seksual pada trimester III dipengaruhi oleh beberapa faktor seperti kepala janin yang menonjol, inkontinensia urin, berat badan pasangan yang akan menekan uterus, perut yang semakin membesar yang akan menghambat pergerakan ibu hamil. ${ }^{16}$ Selain perubahan fisik, hormonal juga terjadi perubahan psikologis. Jika hubungan ibu hamil terhadap pasangannya baik maka akan menimbulkan rasa percaya diri pada ibu hamil tersebut sehingga akan menimbulkan rasa nyaman terhadap pasangannya. ${ }^{17}$

Berdasarkan hasil penelitian didapatkan bahwa pada domain lubrikasi, orgasme, kepuasan dan nyeri hanya sedikit ibu hamil yang mengalami gangguan namun dari hasil statistik tidak terdapat hubungan yang signifikan antara domain tersebut terhadap kehamilan. Hal ini berbeda dengan penelitian yang dilakukan oleh Tunardy et al bahwa Pada domain lubrikasi, kebanyakan mengalami gangguan di trimester ke tiga. Domain kepuasan pada trimester pertama cnderung menurun diduga akibat rasa bersalah yang timbul setelah melakukan hubungan seksual, dimana beberapa sampel 
merasaa khawatir mengenai bayinya.

Sedangkan pada trimseter kedua, kepuasan seksual hampir tidak mengalami gangguan.

Pada trimester ketiga, doamin kepuasan kembali mengalami gangguan akibat perasaan tidak nyaman yang muncul sehubungan dengan kehamilan yang bertambah besar. $^{18}$

\section{KESIMPULAN DAN SARAN}

Seiring bertambahnya usia kehamilan akan menyebabkan

peningkatan kecendrungan terjadinya ganggguan fungsi seksual. Pada kehamilan terjadi perubahan hormonal sehingga mempengaruhi domain fungsi seksual berupa gangguan pada kemauan, gairah.

Perlu dilakukan penelitian selanjutnya untuk mengidentifikasi faktor-faktor yang dapat mempengaruhi fungsi seksual selain kehamilan dan untuk menilai fungsi seksual pada pria ketika pasangannya sedang hamil. Perlu penelitian yang lebih menspesifikkan lagi kategori riwayat melahirkan terhadap fungsi seksualnya, serta dapat dilakukan penelitian selanjutnya membandingkan tingkat kepuasan menggunakan kuesioner FSFI dengan kuesioner lainnya.

\section{DAFTAR PUSTAKA}

1. Khamis MA, Mustafa ME, Mohamed SN, Toson MM. Influence of Gestational Period on Sexual Behavior. The Journal of the Egyptian Public Health Association: 2007; 82 (1-2); 6590.

2. Leite APL, Campos AAS, Dias ARC, Amed AM, Souza E. Prevalence of sexual dysfunction during pregnancy. Rv Assoc Med Bass: 2009; 55(5), 563-568.

3. Santiago LRS, Alves L, Lara S. Impact of pregnancy on the sex life of women: state of the art. International Journal of Clinical Medicine: 2013; 4: 257-264.

4. Fok W, Chanb LY, Yuen PM. Sexual behavior and activity in Chinese pregnant woment. Acta Obstet Gynecol Scand: 2005; 84:934-938.

5. Johnson, CE. Sexual Health during Pregnancy and the Postpartum (CME). The Journal of Sexual Medicine: 2011, 8(5): 12671284.

6. Addis I, Stephen K, Van DE, Cristina I, Wassel-fyr, Eric v, Jeanette B, David HT. Sexual activity and function in middle-aged and older women. Journal of obstetricgynecologist: 2006, 107(4):755-764.

7. Guleroglu FT, Beser NG. Evaluation of sexual functions of the pregnant women. J Sex Med: 2014. 14; 146-153.

8. Elder JA, Braver Y. Female sexual dysfunction: 2010. Diakses dari http://www.clevelandclinicmeded.com Agustus 2016.

9. Rosen R, Brown C, Heiman J, Leiblum S, Meston C, Shabsigh R, et al. The female sexual function index (FSFI) : a multidimensional self-report instrument for the assessment of female sexual function. J Sex Marital Therapy: 2000. 26(2):191-208.

10. Pauleta JR, Nuno MP, Luis MG . Sexuality during pregnancy. J Sex Med: 2010. 7: 136142

11. Kuljarusnont S, Russameecharoen K, Thitadilok W. Prevalence of sexual dysfunction in Thai pregnant women. Thai journal obstet gynaecol: 2011, 19(4): 172-180. 
12. Corbacioglu A, Bakir VL, Akbayir O, Goksedef BPC, Akca A. The role of pregnancy awareness on female sexual function in early gestation. J Sex Med: 2012. 9: 1897-1903.

13. Sulin, Djusar. Perubahan anatomi dan fisiologi pada perempuan hamil. Dalam: Prawirohardjo S. IImu kebidanan. Jakarta: Bina Pustaka Sarwono Prawirohardjo: 2010. pp: 174-186.

14. Guyton AC, Hall JE. Buku Ajar Fisiologi Kedokteran Edisi 11. Jakarta: EGC: 2007.

15. Widiasmoko S. Perilaku kegiatan seksual pada wanita hamil. Obstetri dan Ginekologi Fakultas Kedokteran Universitas Diponerogo Semarang. 2000.
16. Read, Jane. ABC of sexual health: sexual problems associated with interfertility, pregnancy, and ageing. BMJ:2004. 329: 559561.

17. Regan PC, Lyle JL, Otto AL, Joshi A. Pregnancy and changes in female sexual desire: a review. Social Behavior And Personality: 2003. 31(6):603-612.

18. Tunardy El, Manoe M, Tessy T. Perubahan fungsi seksual pada masa kehamilan primigravida. Makassar: Bagian Obsentri Dan Ginekologi Fakultas Kedokteran Universitas Hasanuddin: 2013 